\title{
Political Discourse Analysis (PDA): theoretical and practical considerations
}

\author{
Análise do Discurso Político (PDA): considerações teóricas e práticas
}

Vilmar Ferreira DeSouza

DOI: $h t t p: / / d x . d o i . o r g / 10.5902 / 2176148532001$

\begin{abstract}
The goal of this text is to report on what was developed in DeSouza (2011) and expanded in DeSouza (2015) and DeSouza (2018). The main aim of that work was to examine Padre Cícero's political discourse at the apex of Juazeiro do Norte's bid for independence, in 1911. Thus, this text first discusses political discourse proper and then moves on to the two broad theoretical frameworks used there, namely, Systemic-Functional Grammar (SFG) and Critical Discourse Analysis (CDA), as proposed by Halliday e Fairclough, respectively. From SFG, I focused on the experiential and interpersonal meanings; from the latter I dealt with the concepts of ideology and hegemony. The results showed that most of the power Padre Cícero exerted on the politics of his time stemmed from his careful use of language to represent people and events and to enact powerful social relations.
\end{abstract}

Key words: Political Discourse Analysis (PDA). Systemic-Functional Grammar (SFG). Critical Discourse Analysis (CDA). Ideology. Hegemony.

Resumo: O objetivo deste texto é relatar o que foi desenvolvido em DeSouza (2011) e expandido em DeSouza (2015) e em DeSouza (2018). O objetivo principal daquele trabalho foi examinar o discurso político do Padre Cícero no ápice da candidatura de independência de Juazeiro do Norte, em 1911. Desse modo, este texto discute, em primeiro lugar, o discurso político per se e, em seguida, aborda os dois construtos teóricos utilizados, a saber, a Gramática Sistêmico-Funcional (GSF) e a Análise Crítica do Discurso (ACD), conforme propostos por Halliday e Fairclough, respectivamente. Da GSF, concentrei-me nos significados experienciais e interpessoais; da ACD, o foco recaiu sobre os conceitos de ideologia e de hegemonia. Os resultados mostraram que a maior parte do poder que Padre Cícero exercia sobre a política do seu tempo se devia ao uso cuidadoso da linguagem para representar pessoas e eventos e para forjar relações sociais de poder.

Palavras-chave: Análise do Discurso Político (PDA). Gramática Sistêmico-Funcional (SFG). Análise Crítica do Discurso (CDA). Ideologia. Hegemonia. 
Vilmar Ferreira

DeSouza

\section{Opening lines}

In a world overthrown by political crises from north to south and beyond focusing on political discourse analysis constitute a key source to investigate the role language plays in this fast-changing realm of political battles and its subsequent redesigning of world political geography. From the Syrian conflict to the rise of Islamic State role, from Trump's controversial Immigration Ban, in the United States, to Rousseff's impeachment in Brazil, to name but these, the world is faced with a big array of political battles. To better understand the key motivations underlying these events and more specifically the role language plays at serving different political actors in those conflicts and in many others may seem a sound justification for investing in an area called Political Discourse Analysis (PDA).

Put this way, it may seem that this invitation is something brand new in the field of language studies, a rush conclusion totally misleading. If we consider the Greek Rhetoric enterprise as a genuine project of political discourse analysis, to stay in the West only, we have to accept that there is nothing new in the horizon. Yet, echoes for investing in this area can be traced, more recently, to Chilton (2004)'s Analysing political discourse, Charaudeau (2006)'s Discurso Político [The political discourse] and Fairclough and Fairclough (2012)'s Political discourse analysis, to stay with these only.

The question that arises here is: how to justify another text claiming for a revival of political discourse analysis without being redundant? For one reason, at least, this work seems to offer a fresh answer to that question: by coupling a linguistic language theory, namely, Systemic Functional Grammar (SFG), as proposed by Halliday and Matthiessen (2004, and elsewhere) with a language approach, namely, Critical Discourse Analysis (CDA), as proposed by Fairclough (2001, and elsewhere), to investigate Padre Cícero's political discourse. Thus, the present text relies almost entirely on DeSouza $(2011)^{11}$, which utilized the two frameworks above to examine four letters (L1 ... L4) exchanged between the main social actors involved in the fight of Juazeiro do Norte for political emancipation, of which Padre Cícero stands alone as the main political figure. From SFG, the focus of that

11 I would like to thank Dr. Pedro Henrique Lima Praxedes Filho, Dr. Maria Lúcia Barbosa de Vasconcellos and Dr José Luiz Meurer (in memoriam) for their inspiring work during the unfolding of my doctoral dissertation. 
work laid on the ideational and interpersonal meanings of Padre Cicero's discourse; from CDA, the focus fell on the concepts of ideology and hegemony at the explanatory level.

This text is organized as follows: first, some time will be spent on political discourse per se, looking at what it is, what purposes it may serve and the disciplines occupied with it; second, the areas of the frameworks above will be briefly discussed and applied and, finally, an invitation will be forwarded to scholars to dig deeper into PDA.

\section{A case for Political Discourse Analysis (PDA)}

Any discussion on political discourse proper faces from the very outset at least three big challenges: the first, to define what political discourse actually is; the second, to discuss the many disciplines occupied with the field and, Political discourse analysis (PDA) the third, to justify the purpose for analyzing political discourse itself.

Inasmuch as the first challenge is concerned and agreeing with Gastil (1992, p. 469) that "[p]olitics and discourse are inextricably intertwined", the definition of political discourse bears some complexity. Actually, following the same author informing that "[s]cholarly work on political discourse dates back (or predates) Aristotle" (p. 469), it suffices to note that back in Greek tradition of political investigation by Aristotle, political theory was an ancillary aspect of a broader Aristotelian project: a moral theory, that is to say, politics towards the achievement of "the collective good" (TAYLOR, 1995, p. 235).

If the achievement of "the collective good" implies "participation in a specific political organization" (TAYLOR, 1995, p. 235), it follows then that the path to this "collective good" must incorporate (implicitly or explicitly) a tension between political actors with different political stands. Within the Aristotelian framework, human beings are inherently political beings, and any piece of discourse is a priori political.

This line of reasoning does little to help any one researcher interested in narrower and more feasible definitions of political discourse. Luckily, other scholars have proposed more tailored definitions as is the case with Graber (1981, cited in GASTIL, 1992, p. 469), for whom political discourse takes place "when political actors, in and out the government, communicate about political matters, for political purposes".

This definition aligns itself with Chilton's (2004) definition of politics as either "a struggle for power, between two who seek to assert and maintain power and those who seek to resist it" or "as cooperation, 
as the practices and institutions that a society has for resolving clashes of interest over money, influence, liberty, and the like" (p. 3). Additionally, Reisigl (2008, p. 97) defines 'political' as “... everything politicians do in the pursuance of their political profession". These definitions of politics and political discourse profoundly delimit the boundaries of political discourse proper, which has been investigated by so many disciplines within so many theoretical backgrounds, as Gastil states:

Vilmar Ferreira

DeSouza

126

The literature on political language comes from a variety of fields, including discourse analysis, conversation analysis, linguistics, linguistic anthropology, political science, psychology, sociology, history, philosophy, rhetoric, communication science and cultural studies. Disciplinary boundaries have resulted in a multitude of synonymous and overlapping theories and concepts (GASTIL, 1992, p. 470).

Having approached the two first issues, I now address the purpose of analyzing political discourse itself. In this direction, Gastil (1992) informs that "[d]emocracy, as Wilson inadvertently suggests, can serve a guide for political discourse analysis. In an important sense, one who adopts this view does not have to sacrifice the objectivistic ethic" (p. 471), although the elements of a democracy, for that author, means "an abstract definition of fully democratic discourse" (p. 472), and, as such, this "fully democratic discourse" is unreachable because, as the author says, “... existing and future polities can strive toward it, but they can never reach it” (p. 472).

To sum up, the following features are constitutive of the present work: a) the political standpoint I assume here is that of a democracy as suggested by Gastil (1992); b) the definitions of political discourse and, as a consequence, of politics are those proposed by Reisigl (2008) and Chilton (2004), and c) in accordance with Reisigl (2008) and Gastil (1992), the present approach is also interdisciplinary in nature, encompassing the dimensions of GSF and CDA.

Following Chilton's (2004) definition of politics as "a struggle for power, between two who seek to assert and maintain power and those who seek to resist it", it means that the struggle for power in either case involves necessarily at least two political actors (PA1 and PA2) fighting over an issue at issue (II) as Figure 1 shows: 


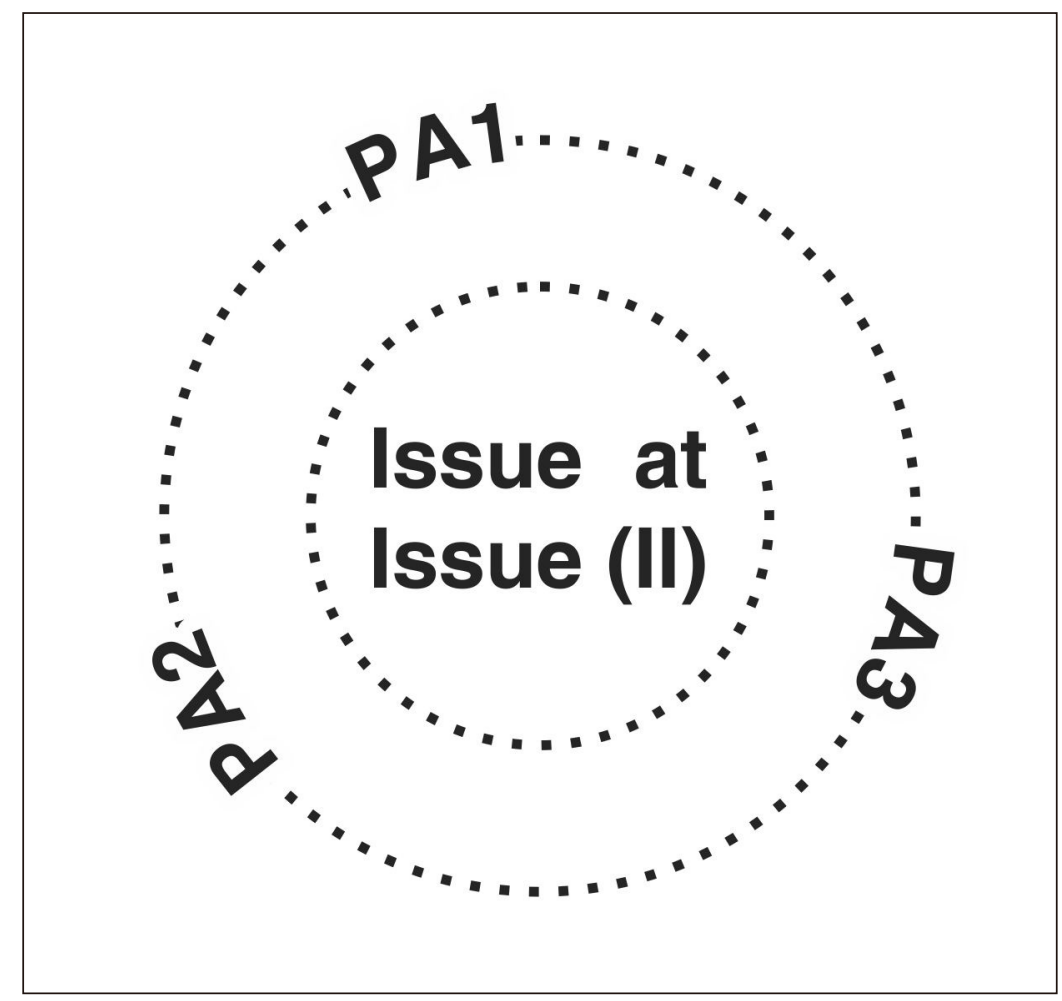

Political

discourse

analysis (PDA)

Figure 1: Political discourse and its social actors ${ }^{22}$

Source: The author.

Thus particularized, Padre Cícero's political discourse comprised of 4 letters published in 1911 and addressed to the Governor of Ceará, Col. Nogueira Accioly (1), and to the Mayor of Crato, Col. Antônio Luís (2) - will be discussed in the light of SFG and CDA.

\section{Systemic-Functional Grammar (SFG)}

Systemic-functional grammar (SFG) has proved to be one the most fertile fields of language investigation these days. Emerging from work on the functional nature of language developed by Halliday in the early 60's, it grew to become a dominant linguistic field culminating with the fourth edition of An Introduction To Functional Grammar (HALLIDAY; MATTHIESSEN, 2014). This academic effort has resonated globally with many grammars being published using SFG

22 I thank my Letras undergraduate students, at IFCE- campus Crateús, José Roberto Romeu Gomes and Antonio Soares da Silva Júnior, for their contribution to the present work. The former drew the Figures 1,2, 3 and 4 and the latter assisted me with the formatting job. 
Vilmar Ferreira

DeSouza

128

as a guiding paradigm such as Lavid, Arus, and Zamorana-Mansilla's (2010) Systemic functional grammar of Spanish - a Contrastive study with English, for instance.

The organizing principle of SFG is not the structure, as is the case with formalist grammars, but the system, organized paradigmatically in terms of choices the users have at their disposal to draw upon against other choices available in the system (the systemic aspect of SFG). The structures are a consequence of the actual choices made; they are the realization of the choices as a sequence of structural functions (the functional aspect of SFG). The ongoing choices of items in a given intralinguistc system network is closely constrained and/or activated by extralinguistic elements of the context, which encompasses the context of situation and context of culture.

The context of situation includes, according to Halliday (1999), "[...] three significant components: the underlying social activity, the persons or 'voices' involved in that activity, and the particular functions accorded to the text within it" (p. 10), technically labeled field, tenor, and mode of discourse, respectively, whereas the context of culture means "[...] the traditional life styles, beliefs, and value systems of a language community" (p. 17).

Language, thus, puts at work, simultaneously, extralinguistic as well as intralinguistic elements. At the intralinguistic semantic stratum, its three metafunctions are: the ideational or reflexive function, which encompasses experiential and logical meanings; the interpersonal or active function, which has to do with interpersonal meanings, and the textual or enabling function, which provides the construal of cohesive and coherent ties in texts. These semantic categories also align themselves with the stratum below of lexico-grammar, constituted of three systemic areas: the system of transitivity, the systems of mood and modality, and the systems of theme and information.

Each stratum above communicates with one another through a relationship of realization. This means that one stratum realizes/ construes another immediately superior which, in its turn, is realized by/activates the one immediately inferior. Put it in another way, the variable field of the context of situation, for example, is realized by/ activates the ideational meaning area of semantics, which is realized by/activates, at the lexicogrammatical stratum, the systems of transitivity and tactic and logico-semantic relations, whose realization 
is the activation of choices at the expression stratum of phonology or graphology. This enmeshing of strata and their hierarchical relationships can be better visualized in Figure 2 .

\begin{tabular}{|c|c|c|c|c|}
\hline 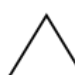 & \multicolumn{4}{|c|}{ Context of Culture } \\
\hline \multirow{4}{*}{ 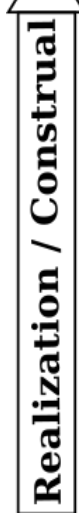 } & $\begin{array}{c}\text { Context of } \\
\text { Situation }\end{array}$ & Field & Tenor & Mode \\
\hline & Semantics & Ideational & $\begin{array}{c}\text { Interper- } \\
\text { sonal }\end{array}$ & Textual \\
\hline & $\begin{array}{l}\text { Lexico- } \\
\text { Grammar }\end{array}$ & Transitivity & $\begin{array}{l}\text { Mood/ } \\
\text { Modality }\end{array}$ & Theme \\
\hline & Expression & Phonolos & & hology \\
\hline
\end{tabular}

Political discourse analysis (PDA)

Figure 2: The SFG strata and their hierarchical relationships

Source: Adapted from Halliday; Matthiessen, (2004, p. 25) $)^{33}$

In DeSouza (2011), the areas of SFG as just outlined used as part of the theoretical apparatus were the experiential and interpersonal meanings as realized, at the lexicogrammatical stratum, by the systems of transitivity and of modality. Because of this, the lines to come will elaborate on these areas.

\subsection{The system of transitivity}

Transitivity is part of the lexicogrammatical system that realizes experiential meanings, construing "a quantum of change in the flow of events as taking place through some input of energy" (HALLIDAY; MATTHIESSEN, 2004, p. 179). This construal of experience of both the internal and external human worlds is achieved through the transitivity configurational functions of process, participant, and circumstance with their respective realizational classes: a verbal group (VG) realizes a process, a nominal group (NG) realizes a participant, and a prepositional phrase or an adverbial group realizes a circumstance. In addition to the above, the ideational

33 This Figure emerged from the work developed by the members of the research group GSF/ACD - SERTÕES - Estudos Interdisciplinares em Gramática Sistêmico-Funcional (GSF) e Análise Crítica do Discurso (ACD), based at IFCE - Campus Crateús. 
Vilmar Ferreira

DeSouza

meanings are also realized by the tactic relations of parataxis and hypotaxis as well as the logical-semantic relations of elaboration, extension, and enhancement.

Halliday and Matthiessen (2004) identify six processes: material, mental and relational - the three major types -, and verbal, behavioral, and existential. Each of these processes possesses its central and additional potential participants. For instance, material processes belong to the semantic space of 'doing' and 'happening' and have as their central participants the Actor, Goal, and Range in addition to Scope, Attribute, and Beneficiary, as their additional participants.

The research question that addressed the experiential meanings of Padre Cícero's political discourse reads like this: how do the transitivity choices made by Padre Cícero in his political discourse reveal his way of representing himself and the other participants in the social practice in fighting for the independence of Juazeiro, namely, Col. Antônio Luís, Col. Nogueira Accioly, and Juazeiro and/or its people?

After completing the transitivity analysis of the 4 letters exchanged between Padre Cícero and the Col. Antônio Luís and Col. Nogueira Accioly, in the fight for the independence of Juazeiro do Norte, in 1911, and discussing each group of process for each of the letters, the results allowed the author to conclude:

\footnotetext{
The findings discussed up to this point allow me to say that Padre Cícero represents himself as being the powerful actor of most events that were crucial for Juazeiro's emancipation, and he achieves this by representing himself as (a) the Actor in the majority of the material processes; (b) the Senser in the majority of the mental processes and (c) the Sayer in some of the verbal processes (DESOUZA, 2011, p. 120-121).
}

This finding, among many others, helps to unveil the subtle strategies Padre Cícero uses to forge a powerful political discourse in favor of Juazeiro's independence. Let me now look at how this works for modality.

\subsection{The system of modality}

Modality refers to an area of interpersonal meanings in which indeterminacy predominates, that is, the shades of meanings are relatively fluid. In Halliday and Matthiessen's (2004) words, “what the 
modality system does is to construe the region of uncertainty that lies between 'yes' and 'no"' (p. 147). This implies that between the assertive "it is so" and the denial "it isn't so" relative to a proposition, that is, language used in exchanges of information, there are two types of intermediate meanings, which are probability and usuality, the dimensions of modality called modalization.

Moreover, if instead of a proposition one has a proposal, that is, language used in exchanges of goods and services, the contrast lies between the positive 'do it' and the negative 'don't do it'. Here again there are two kinds of meaning indeterminacy, depending, in this case, on the speech function, whether it is a command or an offer. The former leads to degrees of obligation whereas the latter leads to degrees of readiness, which, in turn, are divided into the subareas of inclination

Political discourse analysis (PDA) and ability. These two areas of modality are referred to as modulation.

Both dimensions of modalization- that is, probability and usuality-, can be realized in three manners: (a) by a Finite modal operator in the verbal group, (b) by a Modality adjunct, or (c) by both together. As for the dimensions of modulation, obligation and readiness, they can also be realized (a) by a Finite modal operator, or else (b) by an expansion of the Predicator.

In addition to the system of Type, which divides modality into modulation and modalization and their subsequent subsystems of probability and usuality, and obligation and inclination, respectively, the system network of modality contains three other simultaneous systems: VALUE, ORIENTATION, and MANIFESTATION, which will not be considered here for space constraints.

As with transitivity, after the completion of the modality analysis, which involved the breaking of each clause into their constituent elements and their subsequent categorization, the results were discussed as for answering the following research question: how do Padre Cícero's modality choices in his political discourse reveal his way of construing his social role(s) as a powerful or a non-powerful politician as well as his way of construing the social role(s) of his interlocutors, namely, Col. Antônio Luís, Col. Nogueira Accioly, and Juazeiro and/or its people?

The two main findings that emerged from the modality analysis maintain the same alignment with the transitivity results, from which the two macro-figures emerged, that is, of Padre Cícero as a powerful political actor and, at the same time, as a diplomatic peace-maker. 
Vilmar Ferreira

DeSouza

132

Actually, for an illustration and as a general finding, Padre Cícero's political discourse scarcely contains modality. Indeed, out of the 80 clauses present in the two first letters examined, out of four, (L1 and L2), only 14 are either modalized or modulated, that is, only 17 percent of all clauses. This creates an image of his world as overwhelmingly categorical with few spaces for doubt or negotiation, displaying a very poor pattern as for the manifestation of modality.

Now that I have presented the results of the transitivity and modality analyses, at the linguistic level, I move on to present the extra linguistic aspects of that work, which includes a discussion of the concepts of ideology and hegemony based on Critical Discourse Analysis as formulated by Fairclough.

\section{Critical Discourse Analysis (CDA)}

The pioneering work that culminated with what is known today as CDA could be located at the English University of East Anglia whose critical linguistic enterprise developed by a group of scholars resulted in two foundating publications: Language and Control (FOWLER et al., 1979) and Language as Ideology (KRESS; HODGE, 1979).

Their approach to language analysis in these two works already incorporated a good number of current CDA principles such as their "propositions". These include, basically, the following: (a) "[T]he language which we use and which is directed to us embodies specific views - or 'theories'- of reality"; (b) "variation in types of discourse is inseparable from social and economic factors" and (c) "language usage is not merely an effect or reflex of social organization and processes, it is a part of social process" (FOWLER et al., 1979, p. 1).

Although the group of East Anglia University has made some impact on the studies of language and society in the late 60s and early 70s, the birth place and date of CDA, the way it is conceived today, is located some thirty years later in time and a lot more miles away from England. Actually, Wodak and Meyer (2009, p. 4) inform that "CDA as a network of scholars emerged in the early 1990s, following a small symposium in Amsterdam, in January 1991".

The foundation of Fairclough's approach to language and society, though, can be traced to the publication of Fairclough's (1989) Language and Power, in which he not only sets up an agenda for his research project to come but also provides a detailed description of what came to be widely 
known as Critical Discourse Analysis (CDA), whose main aims are (a) to place the studies of language at the center of production, maintenance, and potential change of power relations, and (b) to assist in the increase of consciousness of the power of language in these power relations.

In addition to the above, CDA proponents in general, and Fairclough, in particular, also advocate that critical analysis should encompass not only the dimension of linguistic description but also the dimensions of interpretation and explanation that are meant to connect language to the wider structures of society. In Fairclough (1995)'s words:

\footnotetext{
The method of discourse analysis includes linguistic description of the language text, interpretation of the relationship between (productive and interpretative) discursive processes and the text, and explanation [italics in the original] of the relationship between the discursive processes and the social processes. (FAIRCLOUGH, 1995, p. 97)
}

The project of CDA is, because of this, a way to unveil unequal relations of power in as many varied social settings as possible and, as a consequence, there is the widespread understanding that doing research within the framework of CDA is doing research with a positive attitude against any kind of power manipulation or domination.

The CDA analytical tools used in DeSouza (2011) belonged to the dimension of explanation, which included the concepts of ideology and of hegemony meant to assist in the understanding and explanation of Padre Cícero's political discourse. Given the status of these two concepts, they will be discussed separately.

\subsection{The concept of ideology}

The concept of ideology has entertained scholars from a range of sciences and disciplines for over a hundred years or so as the works by Kress and Hodge's (1979) Language as Ideology, Thompson's (1990) Ideology and modern culture, and Zizek's (2009) The Sublime Object of Ideology attest. In adding to this, Koerner's (2001) acknowledges that

[i]f someone like the French non-Marxist sociologist-philosopher Raymond Boudon, in a 330-page monograph devoted to the origin and diverging uses of 'ideologie' (Boudon, 1986), did not 
succeed in coming up with a universally accepted definition of the term, nor succeeded in rescuing it from its largely negative connotations, I shall no try to bore the audience with my own attempt (p. 253)

Vilmar Ferreira

DeSouza

Certainly, the picture that emerges is totally discouraging. Yet, if the concept of ideology was to be used as an analytical tool, the challenge to turn it into an operationalizable construct was unavoidable. The term ideology was first used by the French philosopher Desttut of Tracey, in 1888, for whom 'idéologies' meant simply "a set of ideas" (KOERNER, 2001, p. 10) with educational positive and beneficial connotations. However, under Napoleon rule, the term was clothed with negative connotations. From this perspective, then, ideology referred to the world of abstract ideas (or ideological) in contrast with the world of practical issues (the political), and, because of this, it did harm to the resolution of practical problems of a political nature in modern society.

This negative and deceiving coloring of the concept of ideology echoed almost unchanged for some decades in the writings of Karl Marx and Frederic Engels, for whom that "set of ideas" was no more than a "false consciousness" (KOERNER, 2001, p. 10). Thanks to a group of scholars closely associated with Marxism but distancing themselves from it in a number of ways, the concept of ideology has regained the positive status it had in Desttut of Tracey's definition. This revisionary group has been collectively known as 'neo-marxists' or 'western marxists' and their most relevant difference from the former Marxists lies in their view that other social dimensions such as the discursive should be incorporated into any scientific analysis of society.

This comprehensive view of ideology is held by most proponents of CDA, including Fairclough (1989), for instance, who, drawing upon Gramsci's (1971) thought, defines ideology as "a conception of the world that is implicitly manifest in art, in law, in economic activity and in all manifestations of individual and collective life" (p. 84).

In being manifest in all human social activities, the constitutive features of ideologies are: (a) they encompass simultaneously a cognitive and a social dimension; (b) they are developed, shared, and reproduced by social actors and reproduces the beliefs and values of the respective social group; (c) they can be negative or positive; (d) ideological content, although being stored in the human mind, is nevertheless accessible to 
human perception through materialized social behavior in the form of social practices; (e) ideology, by nature, is a multiperspective concept and, as such, cannot be approached from any single perspective.

Thus characterized and disregarding its cognitive aspect given the socially oriented stand of this work, the perspectives on ideology in that work were: (1) the anthropological; (2) the sociological; (3) the historical, (4) the political and (5) the semiotic-discursive, which can all be accommodated into the graphic representation in Figure 3.

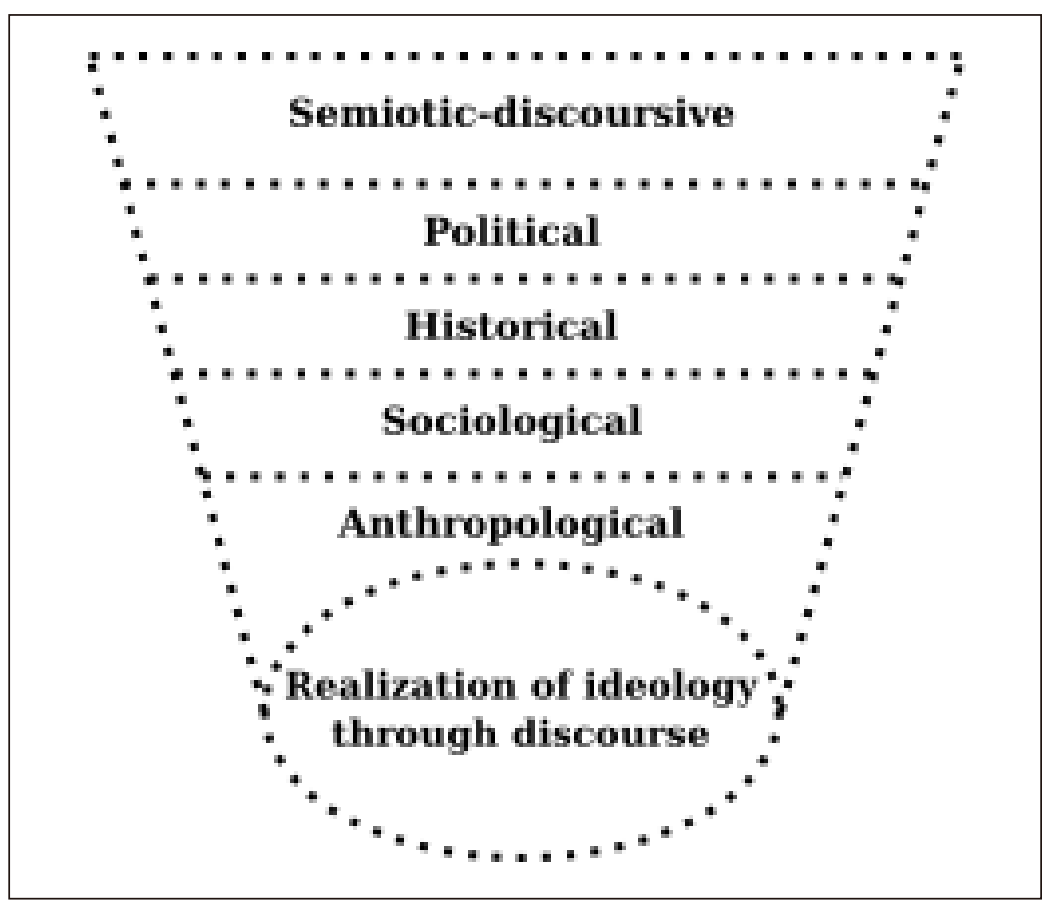

Political

discourse

analysis (PDA)

Figure 3: A graphic representation of the concept of ideology

Source: Based on DeSouza (2015).

Figure 3 should be read as follows: the very first perspective of analysis is that of ideology manifestation in material social life through any observable social practice, be it a discourse-mediated encounter, modes of dressing, and the like. This first perspective of ideology communicates with the others, that is, the way someone dresses, for instance, actualizes ideological content located at any other perspective. Because of the nature of the present piece of research, the perspective of actualization-based approach being considered here is that of ideology being actualized in discourse. 
Vilmar Ferreira

DeSouza

136

The research question focusing on ideology on that work reads as follows: how does the concept of ideology, particularized as being constitutive of discourse, characterized, and defined as previously, help to unveil the meaningful contents of Padre Cícero's political discourse as for the ideological perspectives presented above?

Part of the answer to that research question informs that it is safe to say that the ideological inquiry into the historic level or perspective as presented in Figure 3 helped to clarify at least two points raised earlier, namely, the passivity both of Col. Nogueira Accioly and of Juazeiro and its people, as well as the controversy around Padre Cícero's political role as a coronel. I now turn to hegemony, the second sociological concept used in that work.

\subsection{The concept of hegemony}

Unlike ideology the concept of hegemony does not boast such comprehensiveness of usages or controversy, although it is by no means a simplistic concept. Proof of this is the good number of scholars theorizing on hegemony, such as Laclau and Mouffe's (1985) Hegemony and Socialist Strategy and Gruppi's (1978) O Conceito de Hegemonia em Gramsci [The concept of hegemony in Gramsci], to name but these.

In distancing himself from the Marxist economic determinism, Gramsci (1971) claims that a more coherent analysis of social phenomena is based on what he called hegemony, that is, the subtle mechanisms through which a given social group aims to gain other social groups's consensus through the management of its members' minds towards the construction of a given social order, a goal that can be reached through acquiescence instead of the use of force.

Because the achievement of this social order will never be completed given the fragmentation of interests of many diverging social groups and the articulations and rearticulations of diverging subject positions within these social diverging groups and their struggles for power, the concept of hegemony is only possible to be formulated in the confrontation of these diverging social forces.

[w]e must make clear that when we speak of 'fragmentation' or 'dispersion', it is always with reference to a discourse which postulates the unity of the dispersed and fragmented elements. If these elements are considered without reference to any 
discourse, the application to the terms such as dispersion and fragmentation lacks any meaning whatsoever (LACLAU; MOUFFE, 1985, p. 43).

Because hegemony derives from the intersection of these "dispersed and fragmented elements" (LACLAU; MOUFFE, 1985, p. 43), it produces, in the end, what the authors above call an "unstable equilibrium", when they say that "[...] the hegemonic forms of politics always suppose an unstable equilibrium between this imaginary and the management of social positivity" (p. 190).

Fairclough (2003), elaborating the concept of hegemony as to fit in his analytical framework, acknowledges its roots in Gramsci (1971) and aligns himself with Laclau and Mouffe (1985), by stating that Political discourse analysis (PDA) hegemony is

[a] particular way (associated with Gramsci) of conceptualizing power and the struggle for power in capitalist societies, which emphasizes how power depends on consent or acquiescence rather than just force, and the importance of ideology. Discourse, including the dominance and naturalization of particular representations (e.g. of 'global' economic change) is a significant aspect of hegemony, and struggle over discourse of hegemonic struggles (LACLAU; MOUFFE, 1985, p. 218).

Thus defined and particularized, the features that characterize hegemony are: (1) the emergence of the concept is tied to the advent and development of Neo-Marxism; (2) hegemony considers the possibility of achieving consensus through consent instead of the use of force; (3) this 'consensus' has a fundamental discursive dimension; (4) hegemony implies the existence of "dispersed and fragmented elements", and (5) it constitutes an 'ideal' goal which will never be achieved, constituting nothing else than an "unstable equilibrium" (LACLAU; MOUFFE, 1985, p. 43).

The interpretation I derive from the discussion so far and considering hegemony to be intrinsically this "unstable equilibrium", I suggest that it be graphically represented by a dotted line with an arrow at the end indicating its character of incompleteness, in the way shown in Figure 4. 


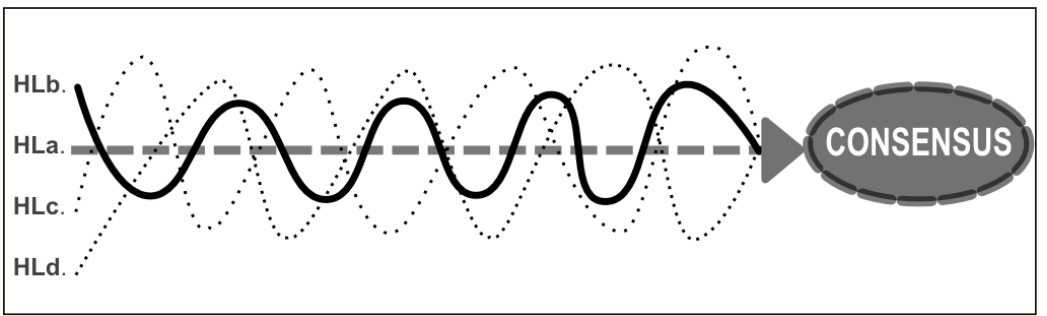

Figure 4. Hegemony's imaginary lines graphically represented

Source: Based on DeSouza (2018).

Vilmar Ferreira

DeSouza

Figure 4 should be read as follows: The hegemonic dotted line (HLa) with the arrow at the end indicates a point in time and space that will never be achieved, that is, a total social consensus will never be arrived at, regardless of the efforts employed in this direction. The bold sinuous line (HLb) with peaks and valleys of equilibrium, aiming to get the closest to the imaginary line (HLa), symbolizes the hegemonic formation led by a ruling social group whose representative at that time was Padre Cícero himself and his attempts to construct a hegemonic discourse towards the independence of Juazeiro do Norte. The two following lines (HLc and HLd) represent, respectively, Col. Antonio Luis, the Mayor of Crato, and Col. Nogueira Accioly, the Governor of Ceará.

The research question derived from this discussion is: how does the concept of hegemony, particularized here as being constitutive of political discourse in particular and characterized and defined as previously, aid to demonstrate whether or not Padre Cícero's political discourse reproduces and/or challenges the hegemonic configurations of his time? At least one aspect of the answer could be the fact that the concept of hegemony helped to construct a configurational hegemonic line that represented the ideological status quo of the political environment in which the fight of Juazeiro's independence unfolded, and, departing from this hegemonic line that was drawn based on the findings at the linguistic level, it was possible to draw the other three hegemonic lines, one for each political actor.

In short and based on those hegemonic lines, it is plausible to say here that, although Padre Cícero seemed to have challenged the status quo of his time by demanding the independence of Juazeiro, he nevertheless did so through a discourse which discursively construed acquiesce rather than used physical force, in alignment with the basic tenets of hegemony. 


\section{Closing lines}

In this work, I discussed the place of Political Discourse Analysis (PDA) within the realm of linguistic inquiry by reporting on what was developed in DeSouza (2011), whose main objective was to analyze Padre Cícero's political discourse through the lens of Systemic-Functional Grammar and Critical Discourse Analysis. I did so by first focusing on political discourse proper and then on the two frameworks above with its specific areas used in that work, alongside the corresponding research questions followed by their tentative answers. Now I may address some more general topics.

To begin with, doing political discourse analysis means to accept that this area of investigation is valid and worth the academic effort in order to better understand the interwoven of political discourses being construed around us all affecting people's lives everywhere. Helping

Political discourse analysis (PDA) people to uncover the misdoings of most of these discourses is an ethical and moral stand worth being pursued.

Although political discourse analysis can be done through various tools from different disciplines, the two frameworks used here proved to be quite enriching and promising. Indeed, the coupling of these two frameworks has long been interwoven as Young and Fitzgerald's (2006) illustrate. If these lines could aid somehow at making this connection even stronger, they were already worth having been written.

\section{References}

CHARAUDEAU, P. Discurso político. São Paulo: Contexto, 2006.

CHILTON, P. Analysing Political Discourse: Theory and Practice. London and New York: Routledge, 2004.

DESOUZA, V. F. The place of the concept of hegemony in Political Discourse Analysis (PDA): a tentative link in the light of Critical Discourse Analysis (CDA) and Systemic Functional Grammar (SFG). In: CABRAL, S. R. S.; BARBARA, L. Estudos sistêmico-funcionais no âmbito do Projeto SAL. Santa Maria: PPGL Editores, 2018. - O lugar do conceito de ideologia na análise do discurso político (ADP): uma proposta à luz da análise crítica do discurso (ACD). Letras, Santa Maria v. 25, n. 50, p. 421-432, jan./jun. 2015. 
Power Relations In Padre Cícero's Epistolary Political Discourse:

An Investigation in the Light of Systemic-Functional Grammar and Critical Discourse Analysis. 173f. Tese (Doutorado em Letras/Inglês e Literatura Correspondente). UniversidadeFederal de Santa Catarina. Florianópolis-SC, 2011.

FAIRCLOUGH, N. Analysing Discourse: Textual Analysis for Social Research. New York: Routledge, 2003.

. Language and Power. $2^{\text {nd }}$ ed. London: Longman, 2001.

Vilmar Ferreira

DeSouza

140

Critical Discourse analysis: the Critical Study of Language.

London: Longman, 1995.

. Language and Power. London: Longman, 1989.

FAIRCLOUGH, N.; FAIRCLOUGH, I. Political discourse analysis. London and New York: Routledge, 2012.

FOWLER, R. et al. Language and Control. London: Routledge and Kegan Paul, 1979.

GASTIL, J. Undemocratic discourse: a review of theory and research on political discourse. Discourse \& Society, n. 3 (4), 1992. p. 469-500.

GRAMSCI, A. Selections from the Prison Notebooks. New York: International Publishers Co., 1971.

GRUPPI, L. O Conceito de Hegemonia em Gramsci. Rio de Janeiro: Edições Graal, 1978.

HALLYDAY, M. K. A. The notion of "context" in language education. In M. GHADESSY (Org.). Text and context in functional linguistics. Amsterdam: John Benjamins, 1999. p. 124.

HALLIDAY, M. K. A.; MATTHIESSEN, C. M. I. M. An Introduction to Functional Grammar. $4^{\text {th. }}$ ed. London: Arnold, 2014.

. An Introduction to Functional Grammar. $3^{\text {rd. }}$ ed. London: Arnold, 2004. 
KOERNER, E.F.K. Linguistics and Ideology in 19th and 20th Century Studies of Language. In DIRVEN, R., HAWKINS, B.; SANDIKCIOGLU, E. (Org.). Language and Ideology. Amsterdam, Filadelphia: John Benjamins, 2001.

KRESS, G.; HODGE, R. Language as Ideology. London, Boston and Henley: Routledge and Kegan Paul, 1979.

LACLAU, E.; MOUFFE, C. Hegemony and socialist strategy. London and New York: Verso, 1985.

Political discourse LAVID, J.; ARUS, J.; ZAMORANA-MANSILLA, M. Systemic functional analysis (PDA) grammar of Spanish - a Contrastive study with English. London and New York: Continuum, 2010.

PRAXEDES FILHO, P. H. L. Linguística Sistêmico-Funcional: linguística teórica Ou aplicada? Linguagem em foco. v. 6/n. 1, p. 11-25, 2014.

REISIGL, M. Analyzing political rhetoric. In: R. WODAK; M. KRZYZANOWSKI (Org.). Qualitative discourse analysis in the social sciences. Nova Iorque: Palgrave Macmillan, 2008.

TAYLOR, C.C.W. Politics. In:J. BARNES (Org.). The Cambridge Companion to Aristotle. Cambridge, New York and Melbourne: CUP, 1995.

THOMPSON, J. B. Ideology and modern culture. Standford, California: Standford University Press, 1990.

WODAK, R; MEYER, M. Methods of critical discourse analysis. Londres: SAGE Publications, 2009.

YOUNG, L.; FITZGERALD, B. The Power of Language. Londres e Oakville: Equinox, 2006.

ZIZEK, S. The Sublime Object of Ideology. $2^{\text {nd. }}$ ed. London: Verso, 2009.

Recebido em fevereiro de 2018

Aceito em abril de 2018 
